\title{
Long-Term Visual Disturbance Affected by Infraorbital Cell Mucocele and Fully Recovered after Surgical Management: A Case Report
}

\author{
Sung Hoon Kim, Ki Nam Kim, and Young Hyo Kim (D) \\ Department of Otorhinolaryngology, Inha University School of Medicine, Incheon, Korea
}

\author{
장기간 시력저하를 주소로 내원하여 수술 후 완전히 회복된 안와하세포 점액종 환자 1 예 \\ 김성훈 · 김기남 · 김영효 \\ 인하대학교 의과대학 이비인후과학교실
}

Received December 20, 2019

Revised January 30,2020

Accepted February 3, 2020

Address for correspondence

Young Hyo Kim, MD, PhD

Department of Otorhinolaryngology, Inha University School of Medicine,

27 Inhang-ro, Jung-gu,

Incheon 22332, Korea

Tel $+82-32-890-2437$

Fax $+82-32-890-3580$

E-mail inhaorl@inha.ac.kr
Mucocele of the paranasal sinuses is a benign, expansible, and cystic mass filled with mucous collection. Infraorbital cells are extramural ethmoid cells that develop into the roof of the maxillary sinus and the base of the orbital cavity. Although infraorbital cells are asymptomatic in most cases, inflammation or mucocele in those cells may cause various symptoms including facial pain, hypoesthesia, and secondary rhinosinusitis. They sometimes invade the orbital cavity, which may cause ophthalmic symptoms such as visual disturbance, orbital swelling, and orbital pain. Most of the cases with ophthalmic symptoms are related to sphenoethmoidal cell mucocele. Delayed treatment of more than two days is known to have a poor prognosis for visual disturbances caused by acute optic nerve compression. We describe a case of 61-year-old man who complained of visual disturbance related to infraorbital cell mucocele and fully recovered right after surgical management.

Korean J Otorhinolaryngol-Head Neck Surg 2020;63(7):330-4

\section{서 론}

부비동의 점액종은 양성, 팽창성 낭종으로 점막 분비물로 이루어져 있으며, 주로 전두동이나 사골동에서 관찰된다. ${ }^{1)}$ 안 와하세포(infraorbital cell or Haller's cell)는 상악동의 지붕 또는 안구의 기저에 발생하는 영역 외 사골동세포(extramural ethmoidal cell)이다. 이것은 여러 위치에서 다양한 크기 로 관찰될 수 있고, 발병률은 2 45\%까지 보고되었다. ${ }^{2)}$ 안와 하세포는 대부분 무증상이지만, 이곳에 염증이나 점액종이 생기면 사골누두(ethmoidal infundibulum)와 상악동 개구 부(maxillary sinus ostium)는 급격히 좁아져, 안면 통증 및

This is an Open Access article distributed under the terms of the Creative Commons Attribution Non-Commercial License (https://creativecommons.org/licenses/by-nc/4.0) which permits unrestricted non-commercial use, distribution, and reproduction in any medium, provided the original work is properly cited.
감각저하, ${ }^{3)}$ 이차적인 상악동염 등이 발생할 수 있다. ${ }^{4)}$ 병변이 안와를 침범한다면 안구부종, 안구통증, 그리고 시력저하가 드물게 나타날 수 있다. ${ }^{5)}$ 점액종으로 인하여 발생한 시력저하 증례의 대부분은 후사골동의 접형사골세포(sphenoethmoidal cell or Onodi cell)가 급격하게 발달하여 시신경에 영향을 준 경우이다. ${ }^{6)}$ 또한 급성 시신경 압박에 의한 시력장 애는 대개 2일 이상 치료가 지연되면 예후가 좋지 않았다. ${ }^{7)}$ 저자들은 안와하세포 점액종으로 장기간 점진적인 시야장애 를 겪은 환자에서 수술 직후 증상의 완전한 호전을 보인 사 례는 문헌상 보고되지 않아 이를 보고하고자 한다.

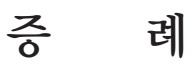

61세 남자 환자로 점진적인 좌측 시야장애를 주소로 내원 

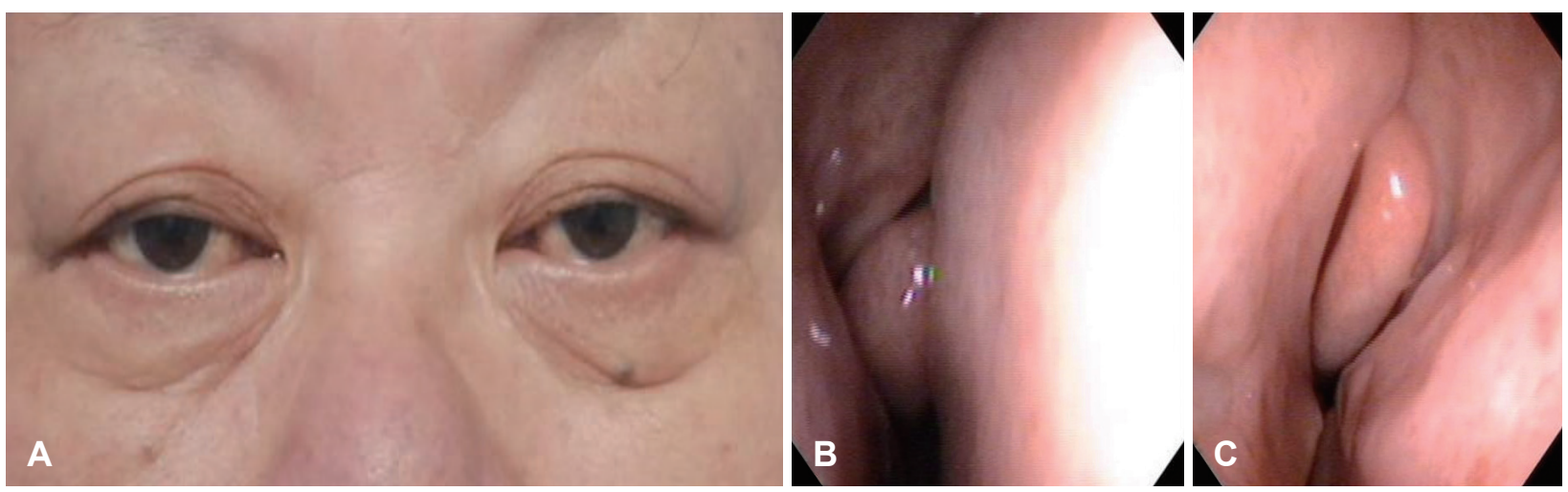

Fig. 1. Preoperative exams show no specific feature at facial photo (A), right nasal cavity (B), and left nasal cavity (C).

하였다. 좌측 시야장애는 1 년 전부터 서서히 진행하였으며, 안과 의원을 거쳐 혈관 문제 감별을 위해 본원 안과 내원하 였다. 두개 내 및 경부 전산화단층촬영 혈관조영술( $\mathrm{CT}$ angiography)에서 안와에 접해있는 비강 내 병변이 관찰되어 수술적 치료 위해 본과에 협진 의뢰되었다.

문진 및 신체진찰에서 안와 주변 발적이나 부종 등이 관찰 되지는 않았고(Fig. 1A) 발열도 없었으며 혈액검사에서 백혈 구 수치(white blood cell)는 $6.37 \times 10^{3} / \mu \mathrm{L}$ 로 정상 수치였다. 시력은 우측이 1.0 으로 정상이었고 좌측은 0.3 으로 낮았다. 동공반사검사에서 좌측 구심성 동공장애(relative afferent pupil defect)의 소견을 보였고, 험프리 정적시야계(Humphrey static perimetry)를 이용한 시야검사에서 좌측에 전반적인 시야 감소가 관찰되었다. 안구운동, 안압, 안저검사에서는 정 상이었다. 비강 내시경 검사에서 양측 비강 내 특이소견 관찰 되지 않았다(Fig. $1 \mathrm{~B}$ and C). 부비동개구연합 전산화단층촬 영 검사(osteomeatal unit CT)에서 후사골동의 외측, 상악동 의 후상방에 안와하세포가 관찰되었으며 내부는 연조직 밀도 (soft tissue density)를 보였다. 해당 병변은 안와를 침범하여 시신경(optic nerve), 내직근(medial rectus muscle) 및 하직근 (inferior rectus muscle)을 압박하였고, 주변 골조직은 전반 적으로 얇아져 있었다(Fig. 2). 상기 소견을 미루어 보았을 때 점진적인 성장을 보이는 안와하세포 점액종으로 인하여 시 각증상이 유발되었을 것으로 의심할 수 있었다. 이에 내시경 적 접근 하에 조대술(marsupialization) 및 안와 감압을 계획 하였다.

후사골동을 제거한 후 측면에서 낭성 구조물이 관찰되어 탐구자(seeker)를 이용하여 개방 시켰고 내부에 차있던 점성 의 액체를 제거하였다. 이후 미세흡입 분쇄기(microdebrider)로 남은 병변을 정리하고 수술을 종료하였다(Fig. 3).

환자는 수술 직후 시력호전을 보였으며 수술 후 2일 째 시 행한 시력검사에서 좌측 시력이 1.0 으로 상승하였다. 수술
후 3 개월 째 경과관찰 시 좌측 시력 0.9 로 유지되었으며, 시 야검사에서도 완전히 회복된 소견을 보였다. 부비동개구연합 전산화단층촬영 검사에서 안와에 작용하던 물리적 압박은 사라졌으며, 안와하벽의 골재형성(bony remodeling)도 확인 할 수 있었다(Fig. 4).

\section{고 찰}

점액종은 양성, 팽창성 낭종으로 점막 분비물로 이루어져 있으며, ${ }^{8)}$ 염증, 외상, 알러지, 또는 선천 구조이상 등이 원인 이 될 수 있다.") 점액종으로 인하여 발생한 시력 저하 증례의 많은 경우는, 후사골동의 접형사골세포가 발달하여 안와에 영향을 미치는 경우이다.) 하지만 본 증례에서는 영역 외 사 골동세포 중 하나인 안와하세포에 점액종이 발생하였고, 1 년 가량의 긴 기간 동안 점진적으로 시력 저하를 유발하였다. 시신경 병증의 병리생리학적 기전은 물리적 압박 또는 염증, 두 가지로 설명될 수 있다. 먼저, 물리적 압박은 안와에 균열 과 골의 재흡수를 유발하고 시신경을 압박하여, 시신경의 허 혈 및 정맥 울혈을 발생시킨다. ${ }^{10)}$ 점액종의 감염은 국소 염증 과 이차적인 시신경염을 유발할 수 있는데,") 이 경우 시신경 이 급격히 압박을 받아 환자는 갑작스러운 한쪽 눈의 실명을 호소하게 된다. ${ }^{11}$

본 증례에서는 안와하세포에서부터 발생된 점액종이 약 1년 간 서서히 시력 저하를 유발하였다. 전산화단층촬영 검사에 서 시신경과 하직근, 외직근을 압박하는 양상을 보였으며, 급 성 염증에 합당한 소견을 보이지 않았다는 점으로 미루어 점 진적으로 확장되는 점액종에 의한 물리적인 시신경 압박이 기 전이라고 유추해볼 수 있다. 점액종으로 발생한 시력문제의 경우, 안과 검진만으로는 그 원인을 찾기 어려우며, 전산화단 층촬영 등의 영상학적인 검사를 시행하여 병변을 확인하여야 한다. 

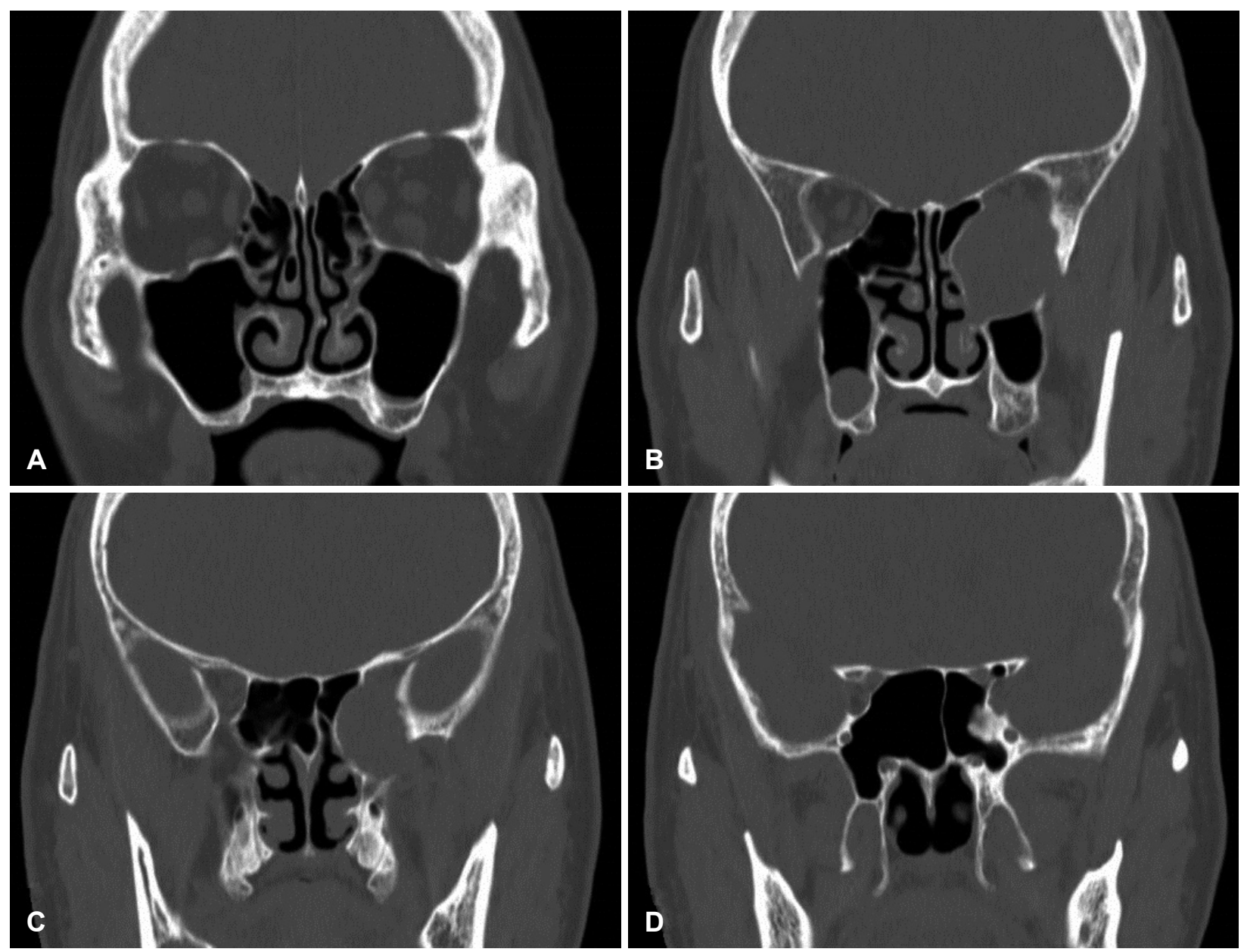

Fig. 2. A series of preoperative osteomeatal unit computerized tomography scans (A-D) shows a round and cystic soft tissue density mass compressing medial and inferior rectus muscles.

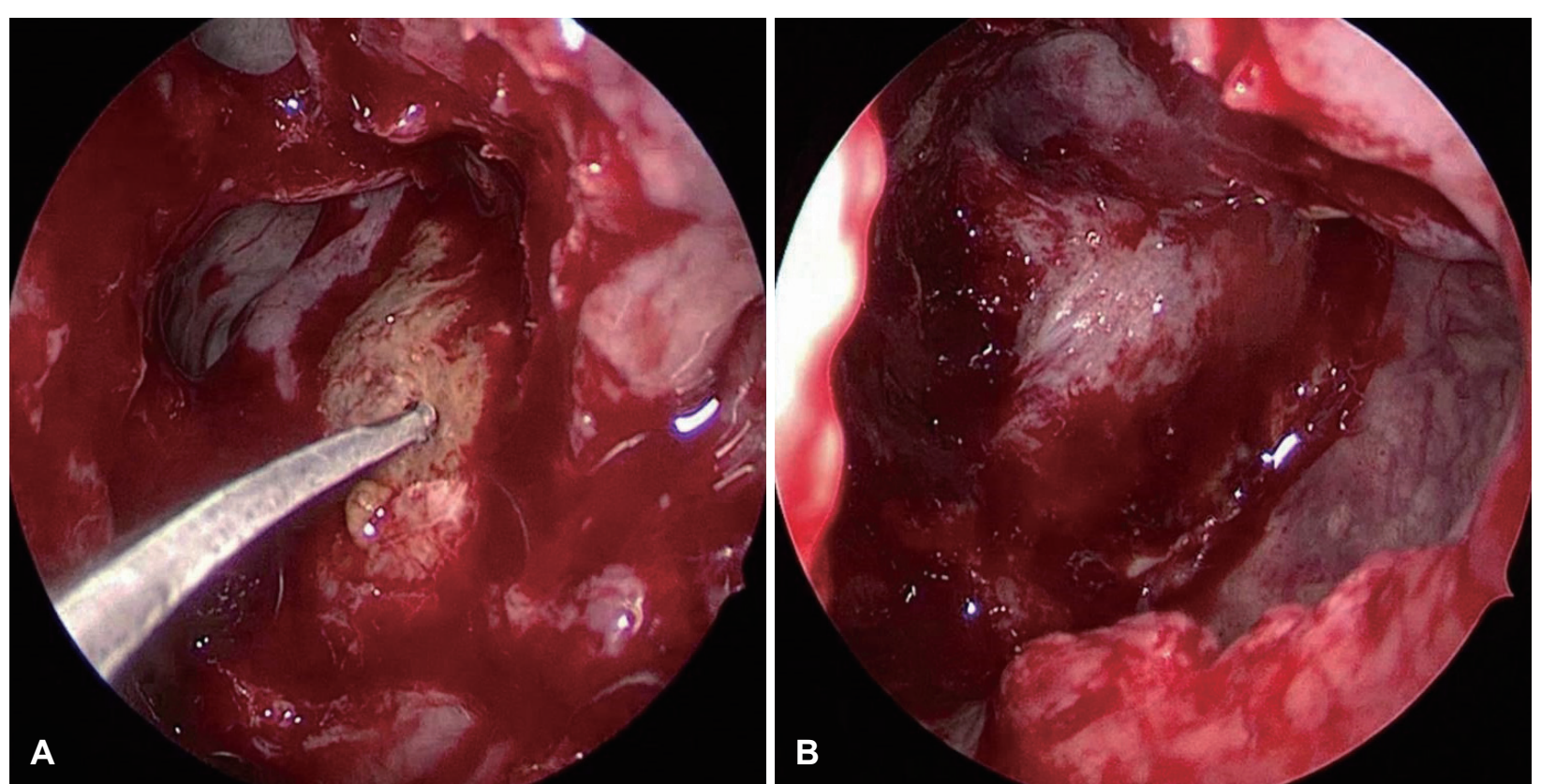

Fig. 3. Opening the lesion with a seeker (A), the infraorbital cell cavity after marsupialization (B). 

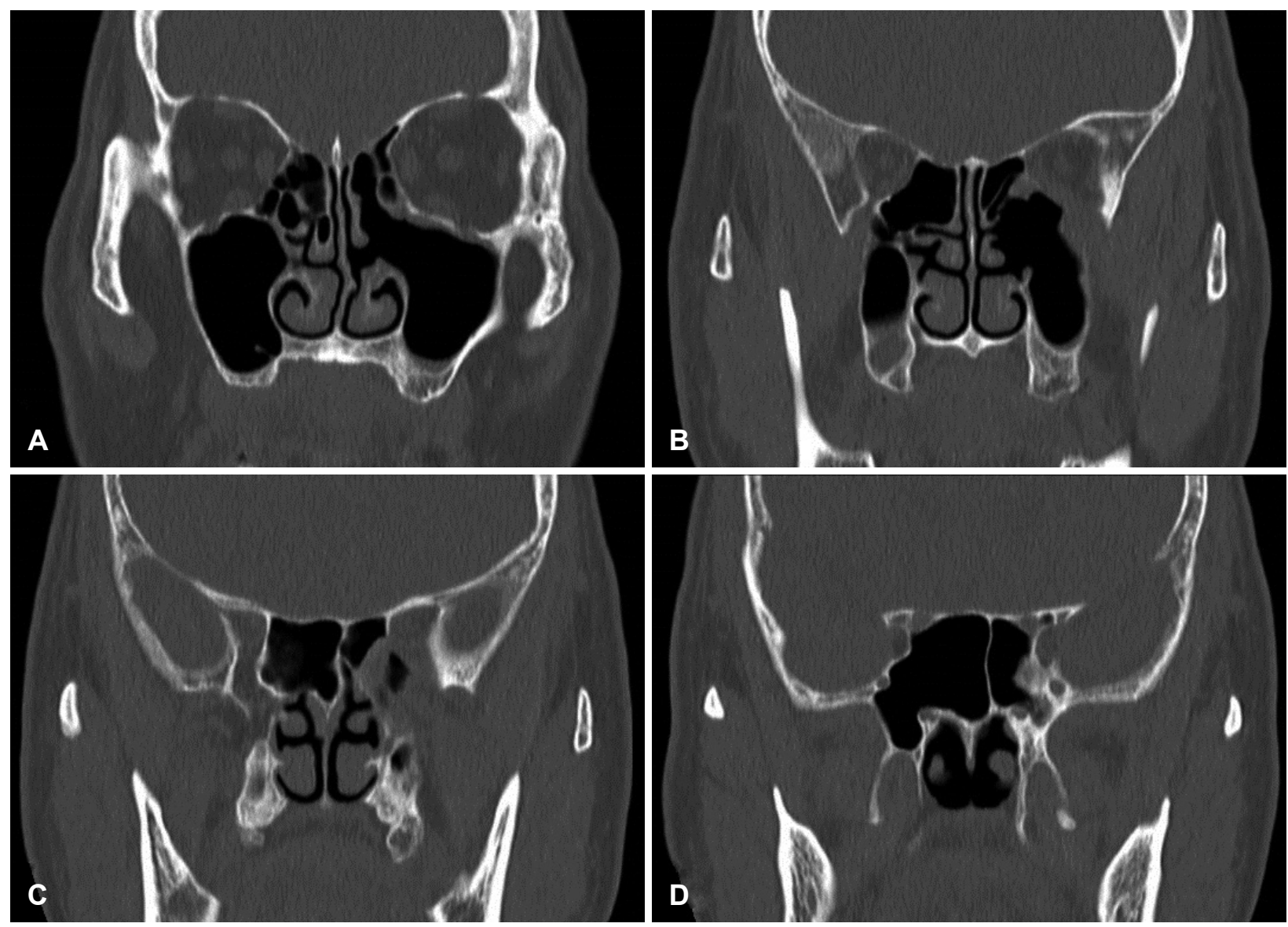

Fig. 4. A series of postoperative osteomeatal unit computerized tomography scans (A-D) shows decreased mass effect to orbit.

점액종에 대한 치료로 조대술을 통한 수술적 제거를 시도 하였다. 비강 내시경으로 시행되는 비강 내 점액종의 배농 및 조대술은 효율적이며, 재발률 또한 낮은 것으로 알려져 있 다. ${ }^{12)}$ 이 증례에서는 점액종과 그로 인한 압박 효과로 인하여, 안와에 미란 소견이 관찰되었다. 따라서 점액종의 상측벽을 무리하게 제거한다면 외안근(extraocular muscle) 및 시신경의 손상이 우려되는 상황이었기 때문에, 내하벽만을 제거하는 조대술을 시행하였다.

여러 연구에서 급성 비강 내 병변에 의한 시력 손실과 시신 경 병증의 조기 인지와 치료의 중요성에 대하여 다루었다. Yumoto 등기는 시력 상실 후 2일 이내에, 감광성 상실 후 24시 간 이내에 감압하면 시력이 완전히 회복될 수 있다고 보고하 였다. 그 이상의 치료 지연이 발생한 경우, 예후는 좋지 않았 다.) 하지만 본 증례에서는 1 년 전부터 서서히 시력 저하가 진 행되었으며, 수술 이후에는 급격하게 시력을 회복하였다. 시신 경에 대한 압박이 오랜 시간 서서히 진행되었다는 점과, 해부 학적으로 안와하세포의 위치가 접형사골세포처럼 시신경에 근접하지 않는다는 점에서, 시신경의 허혈이 부분적으로 발생
하였고, 영구적인 피해는 피할 수 있었던 것으로 생각된다.

사골동 및 상악동 점액종의 급성 악화로 인하여 발생한 이차적인 안와 합병증은 보고된 바가 있다. ${ }^{14)}$ 하지만 안와하 세포 점액종이 다른 부비동으로의 침범이나 급성 염증 소견 없이, 안와를 물리적으로 압박하여 장기간 시력저하를 유발 하고, 수술 직후 완전한 시력의 회복을 보인 사례는 문헌상 보고되지 않아 이를 보고하는 바이다.

\section{Acknowledgments}

None.

\section{Author Contribution}

Conceptualization: Young Hyo Kim. Data curation: Sung Hoon Kim. Formal analysis: Ki Nam Kim. Investigation: Sung Hoon Kim. Methodology: Young Hyo Kim. Supervision: Young Hyo Kim. Visualization: Ki Nam Kim. Writing — original draft: Sung Hoon Kim. Writing — review \& editing: Young Hyo Kim.

\section{ORCID}

Young Hyo Kim https://orcid.org/0000-0002-3623-1770 


\section{REFERENCES}

1) Martel-Martín M, Gras-Cabrerizo JR, Bothe-González C, Montserrat-Gili JR, De Juan-Delago M, Massegur-Solench H. [Clinical analysis and surgical results of 58 paranasal sinus mucoceles]. Acta Otorrinolaringol Esp 2015;66(2):92-7.

2) Stallman JS, Lobo JN, Som PM. The incidence of concha bullosa and its relationship to nasal septal deviation and paranasal sinus disease. AJNR Am J Neuroradiol 2004;25(9):1613-8.

3) Choi JH. Hypoesthesia of midface by isolated Haller's cell mucocele. Braz J Otorhinolaryngol 2016:S1808-8694(16)30138-0.

4) Alkire BC, Bhattacharyya N. An assessment of sinonasal anatomic variants potentially associated with recurrent acute rhinosinusitis. Laryngoscope 2010;120(3):631-4.

5) Sebrechts H, Vlaminck S, Casselman J. Orbital edema resulting from Haller's cell pathology: 3 case reports and review of literature. Acta Otorhinolaryngol Belg 2000;54(1):39-43.

6) Loo JL, Looi AL, Seah LL. Visual outcomes in patients with paranasal mucoceles. Ophthalmic Plast Reconstr Surg 2009;25(2):126-9.

7) Chagla AS, Bhaganagare A, Kansal R, Tyagi D. Complete recovery of visual loss following surgical treatment of mucopyocele of the anterior clinoid process. J Clin Neurosci 2010;17(5):670-2.

8) Victores A, Foroozan R, Takashima M. Recurrent Onodi cell mucocele: Rare cause of 2 different ophthalmic complications. Otolaryngol Head Neck Surg 2012;146(2):338-9.

9) Capra GG, Carbone PN, Mullin DP. Paranasal sinus mucocele. Head Neck Pathol 2012;6(3):369-72.

10) Toh ST, Lee JC. Onodi cell mucocele: Rare cause of optic compressive neuropathy. Arch Otolaryngol Head Neck Surg 2007;133(11):1153-6.

11) Fujitani T, Takahashi T, Asai T. Optic nerve disturbance caused by frontal and fronto-ethmoidal mucopyoceles. Arch Otolaryngol 1984;110(4):267-9.

12) Dhepnorrarat RC, Subramaniam S, Sethi DS. Endoscopic surgery for fronto-ethmoidal mucoceles: a 15-year experience. Otolaryngol Head Neck Surg 2012;147(2):345-50.

13) Yumoto E, Hyodo M, Kawakita S, Aibara R. Effect of sinus surgery on visual disturbance caused by spheno-ethmoid mucoceles. Am J Rhinol 1997;11(5):337-43

14) Simões JC, Nogueira-Neto FB, Gregório LL, Caparroz Fde A, Kosugi EM. Visual loss: A rare complication of maxillary sinus mucocele. Braz J Otorhinolaryngol 2015;81(4):451-3. 